\title{
The Effect of Predict-Observe-Explain (POE) Strategy on Students' Conceptual Mastery and Critical Thinking in Learning Vibration and Wave
}

\author{
Dandy Furqani ${ }^{*}$, Selly Feranie ${ }^{2}$, Nanang Winarno ${ }^{1}$ \\ ${ }^{1}$ International Program on Science Education, Faculty of Mathematics and Science Education, Universitas Pendidikan Indonesia \\ ${ }^{2}$ Department of Physics Education, Faculty of Mathematics and Science Education, Universitas Pendidikan Indonesia \\ *Corresponding Author. dandyfurqani@gmail.com
}

\begin{abstract}
Scientific learning in schools requires not only students' ability to understand concept, but also critical thinking abilities of the students. However, the current scientific learning process is still focused on only cognitive aspects. Therefore, a teaching model or strategy that is able to support students to understand concept as well as develop students' critical thinking abilities is needed. One of the existing needed strategies is Predict-Observe-Explain (POE). The aim of this research is to identify the effects of Predict-Observe-Explain (POE) strategy on students' conceptual mastery and critical thinking in learning vibration and wave. The method that was used in this research was weak experiment and the design was one-group pretest-posttest. The population of this research was 8th grader students in a junior high school in Bandung. The sample of the research was 18 students. The technique that was used was purposive sampling. The results of the research were: There was enhancement in students' conceptual mastery, indicated by average normalized gain of 0,29; There was enhancement in students' critical thinking abilities from level 1,30 (challenged thinker) to 2,07 (beginning thinker). Students can easily predict, observe and explain waves concept have difficulties on transversal waves and longitudinal waves concepts. For the next research it is recommended that Predict-Observe-Explain (POE) is to be tried on motion, electricity and ecosystem.
\end{abstract}

Keywords Predict-Observe-Explain (POE), Conceptual Mastery, Critical Thinking Abilities, Vibration and Wave

\section{INTRODUCTION}

The Indonesian National Curriculum of 2013 stated that learning activities should be focused on students with actively seeking learning patterns and also critical learning (Indonesian Ministry of Education and Culture, 2015). Based on the statement of the Indonesian Ministry of Education and Culture, we can infer that the learning is now emphasized on critical thinking skills of the students. However, according to an interview with a teacher of a middle school in Indonesia, Physics topics such as vibration and wave are considered a tough subject for the students. Vibration and wave, as like as other physics topics, require not only students' knowledge on basic understanding, but also complex thinking, especially to understand the characteristics and types of waves. Therefore, it is necessary to find a more suitable learning model for topics such as vibration and wave.

Critical thinking ability is the ability to think to solve the problem systematically. The purpose of critical thinking is to achieve a deep understanding which is to uncover the meaning behind an event (Johnson, 2010). Critical thinking ability can be sharpened through laboratory activities, discoveries, homework to develop critical thinking skills, and exams designed to build critical thinking skills. Critical thinking skills can be enhanced through group discussions were organized and guided directly by the teacher. Highlevel questions can encourage deeper critical thinking (Wardatun, Dwiastuti \& Karyanto, 2015).

Critical learning emphasizes activities to analyze, interpret, and assess a case or an issue and rationally and logically. Such activities are part of the critical thinking skills. These learning activities require high learning motivation from the students themselves. Motivation to learn can help students develop critical thinking skills because by having the motivation to learn, the students will be more enthusiasm and always feel challenged to keep learning (Ulfah, Asim \& Parno, 2014). Critical thinking as part of thinking skills must be possessed by every member in the community because a lot of problems in life that must be done and finished (Wijaya, 2007). Low critical

Received: 6 September 2018

Revised: 20 November 2018

Published: 2 December 2018 
thinking skills will lead learners to have difficulty when faced with a concrete problem in everyday life.

The main goal of the school is to improve the students' critical thinking ability (Slavin, 1997). However, in fact, the students in the school did not have the opportunity to develop critical thinking skills so that students' critical thinking abilities tend to be low. According to Pratama (2012), the readiness of students to find the best knowledge from a context, confidence to ask, honesty and objectively seek for the information are still low. In fact, someone who has the readiness to find the best knowledge of a context, confidence to ask, honesty and objectively seeks for the information tends to have the nature of critical thinking. Learning activities that are done at school are less able to develop the critical thinking skills of their students. Learning activities that are designed are still lacking in providing critical thinking activities of students, such as activities to analyze, interpret, assessing a case or an issue and rationally and logically, which have been mentioned above (Ulfah, Asim \& Parno, 2014).

Learning is a change indeed through activities, practice, and experience. The paradigm of learning should emphasize on learning itself, is student-centered, should be shifted from "teacher" and "what is to be taught" to the direction of "students" and "what to do". Learning must also create meaningful connections with real life (Hilgard \& Brower in Hamalik, 2009).

According to Kibirige, Osodo \& Tlala (2014), in order to learn, students have to construct knowledge in the learning process. Therefore, the teacher must be able to provide supportive learning environments. Before the learning process begins, students may have different opinion or knowledge about what they are going to learn. During the learning process, students might be not satisfied with they have learned. They may find or seek an explanation that is more acceptable, understandable and meaningful.

Learning can be done by using the previously existing knowledge for new knowledge. The teacher may let the students accommodate, assimilate or replace the previously existing knowledge with the new one. The accommodation, assimilation or replacement, however, often causes misconception among students. Students' prior knowledge should also be considered to make it more of a meaningful

Table 1 One-group pretest and posttest design

\begin{tabular}{lll}
\hline O & $\mathbf{X}$ & $\mathbf{O}$ \\
\hline Pretest: & Treatment: & Posttest: \\
24 multiple & given to the & 24 multiple \\
choice questions & students using & choice questions \\
and 6 essay items & Predict-Observe- & and 6 essay items \\
were given. & Explain strategy & were given. \\
(Dependent & & (Dependent \\
Variable) & & Variable) \\
\hline
\end{tabular}

learning experience for the students (Kala, Yaman \& Ayas, 2012).

In regard to science learning, teachers can involve students to make hypotheses, investigate, and analyze data to develop students' thinking (Wardani, 2017). One model of learning that is capable of developing students' thinking optimally is Predict, Observe and Explain (POE) learning model. POE learning models can include ways that can be taken by a teacher to assist students in improving the understanding of the concept and their psychomotor. POE learning model engages students in predicting a phenomenon, observations through demonstrations or experiments, and finally explain the results of the demonstration as well as their hypothesis. By doing this way, acquired knowledge will be preserved in students' memory and increase students' science processing skills (Zulaeha, Darmadi \& Werdhiana, 2014). To make an active teaching-learning process, students need to be able to clearly express themselves in written form and verbal form; teachers need to introduce a new teaching strategy like the Predict-Observe-Explain (POE) that can be used in association with demonstrations and hands-on activities that can help to enhance classroom practice by identifying the learner's conception (Hilario, J.S., 2015). POE is also suited to be applied in physics subjects that can mostly be observed in experiments, and help to solve misunderstanding (Nana \& Sajidan \& Akhyar \& Rochsantiningsih, 2014). According to the given statements, Predict-Observe-Explain (POE) should be able to be applied as one of the solutions to solve the problem at school regarding the topic of vibration and wave.

The novelty of this research is, this research measures conceptual mastery and critical thinking also analyses students' ability to predict, observe and explain in POE stages. From the problems, it is seen that the teachinglearning process in the school is still not very effective to bring out students' capacity to its full potential, including in topics such as vibration and waves. Therefore, the aim of this study is to investigate the effect of predict-observeexplain (POE) strategy on students' conceptual mastery and critical thinking in learning vibration and wave.

\section{METHOD}

\subsection{Research Method and Research Design}

The method that was used in this study is weak experiment method. Fraenkel, Wallen, and Hyun (2011) stated that this design is weak and do not have built-in control for threats to internal validity. In addition to the independent variable, there are a number of other plausible explanations for any outcomes that occur to find the effect of predict-observe-explain (POE) strategy on students' conceptual mastery and critical thinking in learning vibration and wave topic on 8th-grade secondary school. 
Table 2 The percentage of students' gender

\begin{tabular}{llll}
\hline Population & Gender & $\begin{array}{l}\text { Number } \\
\text { Students }\end{array}$ & $\begin{array}{l}\text { of } \\
\text { Percentage } \\
(\mathbf{\%})\end{array}$ \\
\hline $8^{\text {th }}$ Grade & Male & 8 & 44 \\
Students & Female & 10 & 56 \\
& Total & 18 & 100 \\
\hline
\end{tabular}

Table 3 Stages of the research

\begin{tabular}{ll}
\hline Stage & Activity \\
\hline Preparation & Formulating the problem and research \\
objectives & Defining the dependent and independent \\
& variables of the research \\
& Determining the sample and the population \\
& of the research \\
& Conducting a literature review about \\
& predict-observe-explain (POE) learning \\
& strategy, students' conceptual mastery, \\
& students' critical thinking, and vibration and \\
& wave topic \\
& Designing research instruments \\
& Testing research instrument \\
& Making a revision of research instrument \\
Specifying group for the research \\
Implementation \\
Conducting pretest to the sample group \\
Giving treatment to sample group \\
Conducting posttest to sample group \\
Calculating the data \\
Analyzing the data \\
Making result and conclusion \\
Reporting of the research paper
\end{tabular}

Table 4 Interpretation of indicator of conceptual mastery

\begin{tabular}{lllll}
\hline Pretest & Posttest & Gain & N-gain & Interpretation \\
\hline 29.17 & 50.00 & 20.83 & 0.29 & Low \\
\hline
\end{tabular}

This research used one group pretest and posttest design. Therefore, in this study, the researcher picked one group, conducted pretest, gave treatment, and then conducted posttest. According to Fraenkel, Wallen, and Hyun (2011), in the pretest and posttest experiment, researcher assigns a single group and measure or observe not only after giving a treatment of some sort but also before. This design is detailed in Table 1.

\subsection{Population and Sample}

The population in this research was International Junior High School in Bandung which implements the Indonesian National Curriculum of 2013. The population in this research was 8 th-grade students. The samples were from a class in eighth grade. The samples consist of 18 students with the ages ranging from 13 to 14 years old. 8 students $(44 \%)$ of the samples were male students while the other 10 students $(56 \%)$ are female students.

The sampling technique that was used in this research is Purposive Sampling. According to Fraenkel, Wallen, and Hyun (2011), Purposive Sampling is a sampling, in which researchers do not simply study whoever is available but rather uses their judgment to select a sample they believe, based on prior information, will provide the data they need. There are 18 students from one class that are assigned as samples in this research. The percentage of students' gender is detailed in table 2 .

The stages in this research are represented in table 3.

\subsection{Research Instrument}

The instrument is necessary to be used for gaining data. In this research, the instruments that were used include pretest and posttest. The researcher used pretest and posttest instrument to test the students' conceptual mastery and critical thinking in vibration and wave topic for both the control group and experimental group. The pretest was held before the groups are given treatment, and the posttest was given after the treatment was applied.

Initially, in both pretest and posttest, the students were to be given 50 questions multiple choices tests, consisting of 26 questions to measure students' conceptual mastery and 24 questions to measure students' critical thinking. However, after some considerations and thorough the validation process, the questions were reduced into 24 multiple choices question items for conceptual mastery test and 6 essay question items for critical thinking ability test.

The questions for the students' conceptual mastery are based on Bloom's taxonomy (Anderson et al., 2000), while the questions for the students' critical thinking that are covered by six indicators of students' critical thinking by Ennis.

\subsection{Research Procedure}

The steps of conducting this research consist of three main stages, which are the preparation stage, the implementation stage and completion stage. Preparation stage includes: (1) formulating the problem and research objectives, (2) defining the dependent and independent variables of the research; (3) determining the sample and the population of the research; (4) conducting literature review about predict-observe-explain (POE) learning strategy, students' conceptual mastery, students' critical thinking and vibration and wave topic; (5) designing research instruments; (6) testing research instrument; and (7) making revision of research instrument. Implementation stage includes (1) specifying a group for the research; (2) conducting pretest to the sample group; (3) giving treatment to sample group; (4) conducting posttest to sample group. Completion stage includes (1) calculating the data; (2) analyzing the data; (3) making result and conclusion; and (4) reporting of the research paper.

\section{RESULT AND DISCUSSION \\ 3.1 Analysis of Students' Conceptual Mastery}

In analyzing students' conceptual mastery, students' scores gained from the tests are calculated and compared using data from both pretest and posttest. The average N- 
gain scores are calculated and then interpreted using the criteria based on Hake's. The result is shown in Table 4.

Based on the research, out of 100 score rating, students obtained an average score of pretest of 29.17. In the posttest, students obtained an average score of 50 . Using the average scores obtained in the pretest and posttest, a gain of 20.83 is obtained. Furthermore, an average N-gain score of 0.29 is obtained. This value is interpreted as low according to Hake. The result is shown in figure 1.

Based on Figure 1, there is an enhancement in the posttest compared to the pretest. The initial score obtained by the students measured by the pretest is shown to be 29.17 out of 100 score rating. The students were already informed about holding the pretest before and were not taught by the teacher about the concept before to test their prior knowledge. After the implementation of $\mathrm{POE}$ strategy, the posttest was held to measure students' conceptual mastery about the concept. The result of score 50 out of 100 score rating was obtained from the posttest.

As shown by the data, there is an enhancement in students' conceptual mastery measured in the pretest and the posttest. There is a gain of 20.83 value obtained by comparing students' prior knowledge in the pretest and students' knowledge after being treated by POE strategy by the posttest. It is seen that the value of $\mathrm{N}$ gain is shown to be 0.29 . According to Hake (1999), this value means there is a low gain in students' conceptual mastery in learning vibration and wave using POE strategy.

By using students' score from pretest and posttest, the researcher analyzed the data using SPSS ver.20 to determine whether the data is normally distributed or not. The result is detailed in Table 5 .

In the table, it is shown from the Shapiro-Wilk test that the significance is less than 0.05 . Thus, the data is not normally distributed. In comparison, the significance in the pretest has a value of 0.010 while the posttest has a significance value of 0.35 . Since there is only one class used for the sample and the data is compared to its pretest and posttest score, Wilcoxon test is used to determine the difference. The result is described in Table 6.

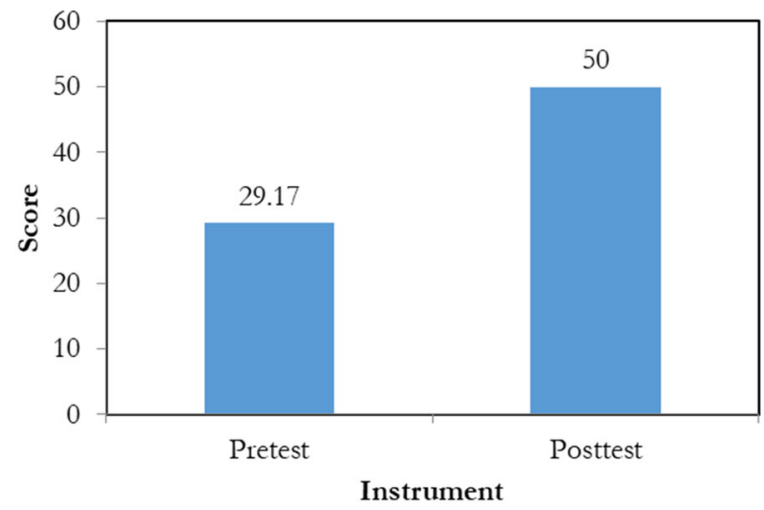

Figure 1 Students' average score on conceptual mastery test
Table 5 Statistical analysis for conceptual mastery test

\begin{tabular}{|c|c|c|c|c|c|}
\hline \multirow{2}{*}{ Instrument } & \multicolumn{2}{|c|}{ Kolmogorov-Smirnov } & \multicolumn{3}{|c|}{ Shapiro-Wilk } \\
\hline & Statistic df & Sig. & Statistic & df & $\mathbf{S i}$ \\
\hline & .220 & .021 & .855 & 18 & .0 \\
\hline Posttest & .235 & .010 & .888 & 18 & .03 \\
\hline
\end{tabular}

Table 6 Statistical result of wilcoxon non-parametric test

\begin{tabular}{ll}
\hline Ty & Posttest - Pretest \\
\hline$Z$ & $-3,742^{\mathrm{b}}$ \\
Asymp. Sig. (2-tailed) &, 000 \\
\hline
\end{tabular}

Table $7 \mathrm{~N}$-gain scores for each aspect of conceptual mastery

\begin{tabular}{llllll}
\hline Level & Pretest & Posttest & Gain & $\begin{array}{l}\text { N- } \\
\text { gain }\end{array}$ & $\begin{array}{l}\text { Inter- } \\
\text { pretation }\end{array}$ \\
\hline C1 & 30.56 & 75.93 & 45.37 & 0.65 & Fair \\
C2 & 30.56 & 47.92 & 17.36 & 0.25 & Low \\
C3 & 27.22 & 36.11 & 8.89 & 0.12 & Low \\
\hline
\end{tabular}

Based on the table, the level of significant value in the test is 0.05 . Since the significant value is 0.00 , which is less than 0.05 , it means there is the difference between students' pretest and students' posttest. The result is supported by Kibirige, Osodo, and Tlala (2014), which found enhancement in students' understanding of the concept. Although, based on the research, different levels of cognitive skills have a different gain. As the cognitive level rise, the more complex the thinking level will be, and less effective Predict-Observe-Explain becomes. Thus, PredictObserve-Explain shows the linear result, supported by Kala, Yaman, and Ayas (2012).

The enhancement is likely due to students' capability in learning through Predict-Observe-Explain stages. In the predict stage, students were required to gather information with their prior knowledge, assisted with reliable sources. In this stage, students seemed to pass it without much difficulty. In the second stage, which is observed, students had to carefully observe the moving pendulum and slinky which and find any information to be obtained as knowledge. In the third stage, students were required to put the knowledge they obtained into words or any other methods to describe, which also require communication skills and comprehensive understanding.

The enhancement in students' conceptual mastery is also analyzed from the average of for each aspect. In this calculation, each aspect of conceptual mastery (C1, C2, and C3) is calculated using multiple choices test in the pretest and posttest. The data obtained are detailed in Table 7.

Based on Table 7, the $\mathrm{C} 1$ level has an $\mathrm{N}$-gain value of 0.65 , which is obtained using pretest and posttest. According to Hake, the $\mathrm{N}$-gain value of the $\mathrm{C} 1$ level is categorized into fair. However, the $\mathrm{C} 2$ level has an $\mathrm{N}$-gain value of 0.25 , which is categorized into low. The C3 level has an $\mathrm{N}$-gain value of 0.12 , which is categorized into low as well. The data is also shown in figure 2 .

From the figure, it is seen that $\mathrm{C} 1$ cognitive level has higher N-gain than C2 and C3 cognitive levels. It is then 
Table 8 Scoring and interpretation of students' critical thinking ability

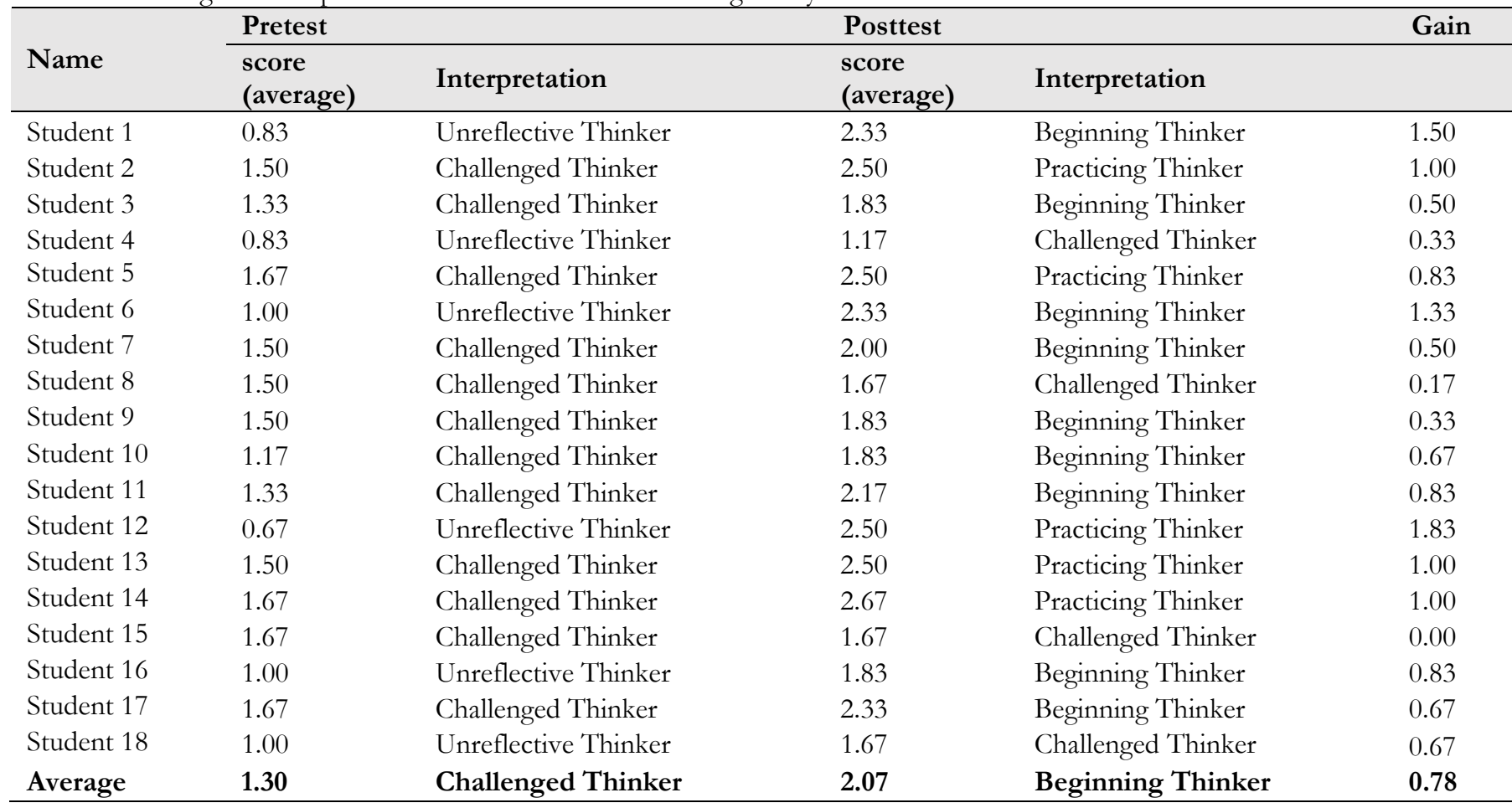

followed by a C2 cognitive level. In comparison, the C3 cognitive level has the least value of $\mathrm{N}$-gain. From the analysis, we see that POE strategy is more effective for the C1 cognitive level (understanding), less effective for the C2 cognitive level (understanding), and least effective for the C3 cognitive level (applying). This happened most likely because C1, C2 and C3 cognitive levels require different thinking levels. According to Clark (2015), the levels can be thought of as degrees of difficulties. That is, the first ones must normally be mastered before the next one can take place. C3 cognitive level requires a higher thinking process than $\mathrm{C} 2$ cognitive level, while $\mathrm{C} 2$ cognitive level requires a higher thinking process than $\mathrm{C} 1$ cognitive level. This result is in accordance with Hilario (2015) that stated that the POE strategy helped students to understand the concept better

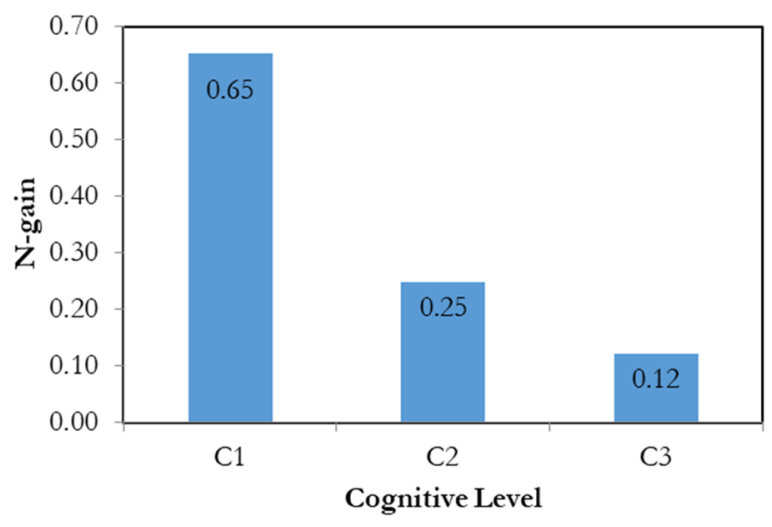

Figure $2 \mathrm{~N}$-gain scores for each aspect of conceptual mastery

\subsection{Analysis of Students' Critical Thinking}

In analyzing critical thinking ability, the researcher uses rubrics to determine the score, which is then interpreted to determine the development of critical thinking skill. The data obtained is as detailed in Table 8.

Based on Table 8, students obtained a score with an average value of 1.30 , which is interpreted as Challenged Thinker according to Paul and Elder. From the posttest, students obtained a score with an average value of 2.07, which is interpreted as Beginning Thinker. These scores are obtained out of 4 score rating using the rubrics. Using the scores, a gain of 0.78 , which is an increase of roughly $20 \%$ from pretest, is obtained by calculating the score of posttest minus the score of the pretest. The example of students' answers is shown in figure 3, figure 4 and figure 5 .

Figure 4 represents the students' answer in the pretest, while figure 5 represents students' answer in the posttest. For the pretest, the representative figure 4.4 obtained score 1 , because the answer is correct but the reason is related to the answer according to the rubric for the scoring, which is "The answer is incorrect and the reason is not relevant to the question". Meanwhile, for 4.5 that is presented in the posttest obtained score 4 , because the answer is correct that the reason given is acceptable according to the rubric, which is "The question is answered correctly and the reason is significant to the question". Both figures are from the same student. During the pretest, students seemed to have many ideas about the concept of vibration and wave with their prior knowledge. During the posttest, students seemed to have set an idea according to the knowledge they obtained and then applied it to solve the problem. 


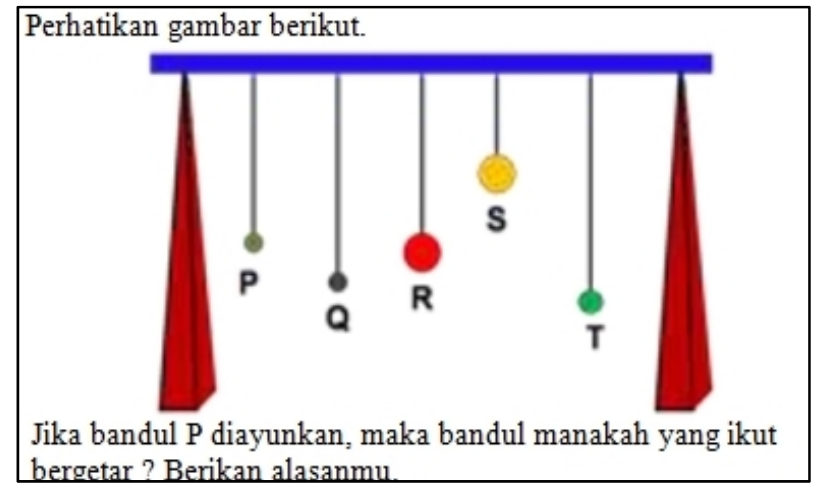

Figure 3 Example of questions used in critical thinking test

B. ESSAY

Jawablah pertanyaan berikut secara singkat dan benar! 1. Semua bondul aken bergerak, korena semua bondul dipengarchi oldh bondul f

Figure 4 Example of students' answer in critical thinking pretest

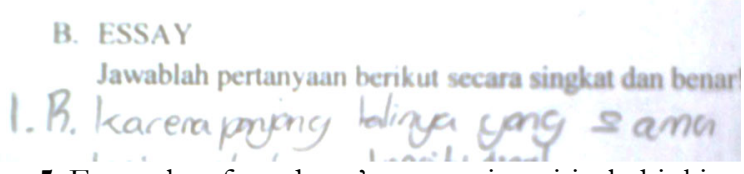

Figure 5 Example of students' answer in critical thinking posttest

The analysis shows that there is a positive result or enhancement of students' critical thinking ability with POE strategy, which is supported by Cholisoh, Fatimah, and Yuniasih (2015) in "Critical Thinking Skills in Integrated Science Learning Viewed from Learning Motivation" that stated that there is a positive effect on the students' critical thinking skills with POE strategy. In table 4.5, there are 17 students that have an increase in thinking level. The increase in critical skills varies from one to two levels. In the pretest, the result shows that students also have a range of critical skill indicated by the scores, with the lowest being 0.67 (Unreflective Thinker) while the highest being 1.67 (Challenged Thinker), which is shown by a number of students. In the posttest, students' critical thinking vary with the lowest being 1.17 (Challenged Thinker) and the highest being 2.67 (Practicing Thinker). We also find that there are two students that did not raise thinking level and stay at Challenged Thinker. In addition, one of the two did not have gain in pretest-posttest comparison.

The enhancement in students' critical thinking is likely to be caused by each stage of POE that corresponds to the aspects of the critical thinking. In Predict stage, students have to make a prediction with their prior knowledge and clarify it with other sources before observing the objects. Once it is set, during observe stage, students have to adjust strategies or tactics to conduct the observation. After the information is obtained, students sum up what they have found during observation and their prior knowledge and make an inference to obtain information. During the process, students are not only required to find the right answer but also to construct the knowledge so that the answer they come with is within the reason they have. Therefore, students should be able to use their further thinking skill to solve the problems during the process.

\subsection{Analysis of Students' Capability in Predict-Observe- Explain (POE)}

In addition to analyzing the data with the test, the researcher also conducted a test to analyze students' gaining capability in POE using the worksheet. The results are shown in figure 6 , figure 7 and figure 8 .

In the predicting stage, as represented in figure 6, students seemed to have roughly no difficulty in predicting the definition of waves. As seen in the diagram, there were no students that obtained 0 scores for the concept of waves. Students mostly have a score of 1 , which are obtained by 15 students (83\%). The rest 3 students (17\%) managed to obtain score 2 in predict stage.

The opposite result of predict stage occurred for transversal waves. Most students failed in predicting transversal waves, which is indicated by the fact that 10 students $(56 \%)$ obtained a score of 0 for predicting transversal waves. 7 students $(39 \%)$ obtained the score of 1 , while 1 student $(6 \%)$ managed to obtain the score of 2 .

As for longitudinal waves, 10 students $(56 \%)$ failed to predict the concept. 5 students $(28 \%)$ obtained the score of 1 , while 3 students $(17 \%)$ managed to obtain the score of 2. As seen on the diagram, the result on predict stage shows a roughly similar result for both transversal waves and longitudinal waves. While students seem to have roughly no difficulty on the definition of waves concept, students seem to have difficulty for an advanced concepts like transversal waves and longitudinal waves. The result is in line with Hilario (2015) that found that students can make sensible prediction through POE. This result is also in line with White and Gunstone (2014) that stated that prediction requires extended knowledge of the problem to solve the given problem so that more complex concept like transversal waves and longitudinal waves are more difficult than the definition of waves concept.

In the observed stage, as represented in figure 7 , we see that 2 students $(11 \%)$ failed with the score of 0 . Roughly 12 students $(67 \%)$ obtained the score of 1 , while the rest 4 students $(22 \%)$ managed to obtain the score of 2 for the concept of the definition of waves. As for transversal waves, 12 students $(67 \%)$ fail with the score of 0 , while 6 students $(33 \%)$ obtained the score of 1 , and no students managed to get the score of 2 . For longitudinal waves, 11 students $(61 \%)$ failed with the score of 0 , while 3 students $(17 \%)$ obtained the score of 1 , and $22 \%$ students managed to get the score of 2 .

Based on the diagram, students seem to be able to perform observation about the definition of waves. However, students still have difficulty for transversal waves and longitudinal waves. The result is in line with Hilario (2015) that found that students can make sensible 


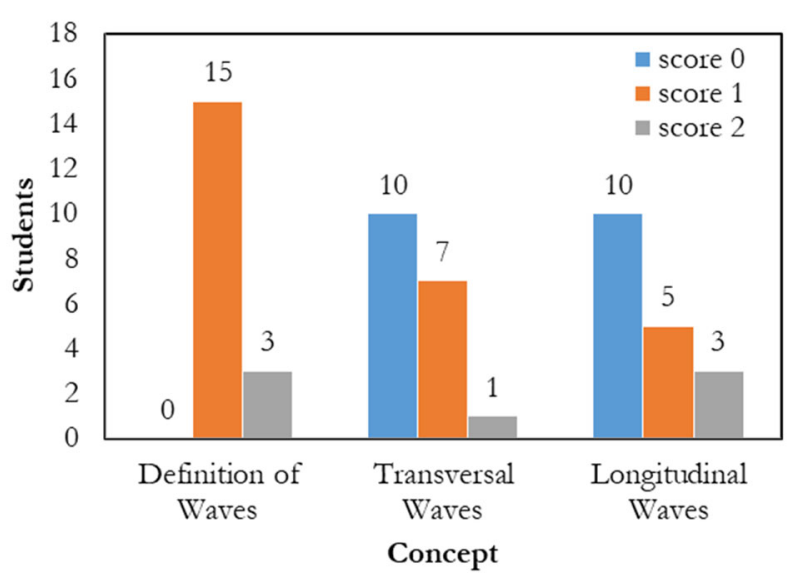

Figure 6 Students' score in predict stage

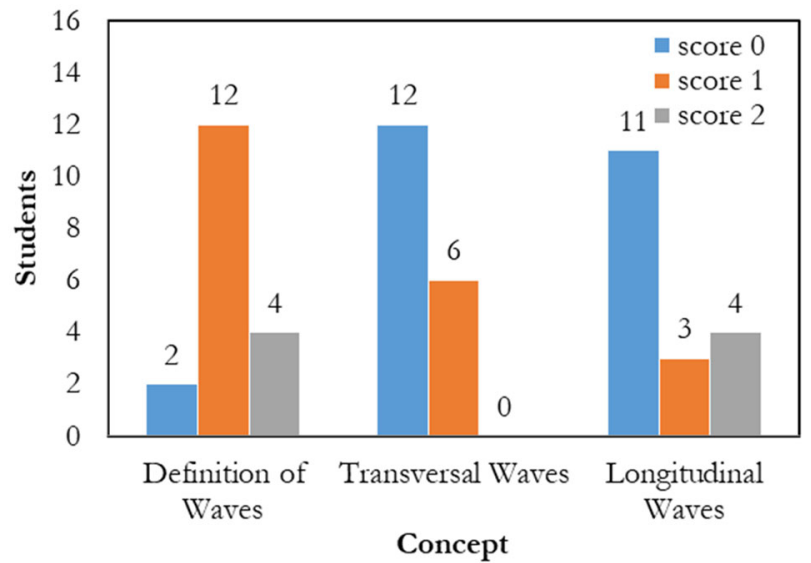

Figure 7 Students' Score in Observe Stage

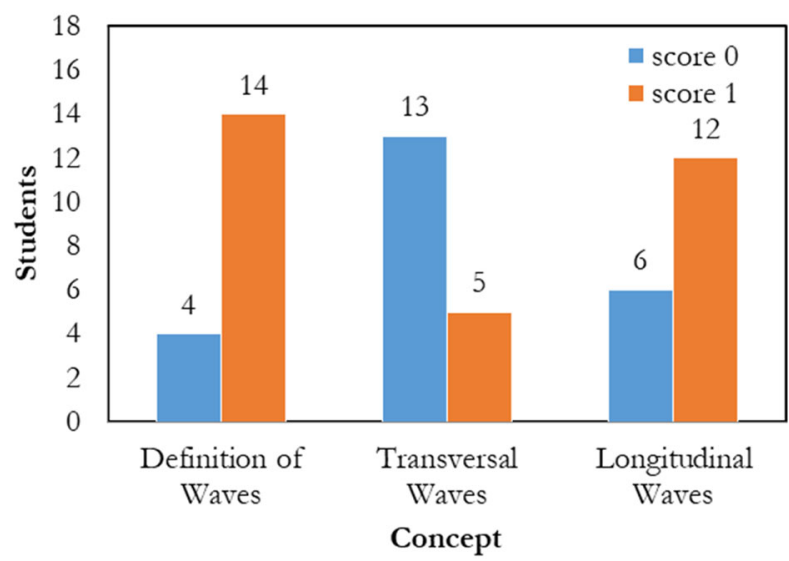

Figure 8 Students' Score in Explain Stage

prediction through POE. This result is also in line with White and Gunstone (2014) that stated that prediction requires extended knowledge of the problem to solve the given problem so that more complex concept like transversal waves and longitudinal waves are more difficult than the definition of waves concept.

In the explain stage, as represented in figure 6 , students seemed to be able to perform with not much difficulty. In the concept of the definition of waves, $22 \%$ of students failed with the score of 0 while the other $78 \%$ of students managed to obtain the score of 1 . In the concept of transversal waves, $72 \%$ of students failed with the score of 0 while $28 \%$ students managed to obtain the score of 1 . In the concept of longitudinal waves, $33 \%$ of students failed with the score of 0 while the rest $67 \%$ students managed to obtain the score of 1 .

Based on the diagram, students have quite the grasp of wave and are able to explain it their own way easier than another concept. Students were also able to grasp the concept of longitudinal waves, though not as easy as wave concept. On the other hand, students seem to have difficulty in learning about the transversal wave, unlike waves and longitudinal waves. This result is in line with White and Gunstone (2014) that stated that prediction requires extended knowledge of the problem to solve the given problem so that more complex concept like transversal waves and longitudinal waves are more difficult than the definition of waves concept. The findings show that there is a possibility that students have a misconception in a transversal wave, which is in line with Kala, Yaman, and Ayas (2012), which found that POE can be used for the teacher to find students' misconception in a concept.

\section{CONCLUSION}

Based on the results on the analysis in the research, it can be concluded that: (1) POE strategy shows enhancement in students' conceptual mastery, indicated by normalized $\mathrm{N}$-gain value 0.29 ; (2) as for critical thinking skills, POE strategy seems suited to enhance critical thinking ability. Using POE strategy, the result showed that students gain increase in critical thinking from level 1,30 (challenged thinker) to 2,07 (beginning thinker); (3) POE is good to implement the knowledge into students. However, in its implementation, it is not effective as a strategy to implement the whole idea into students as students might face difficulty, especially in some stages. Students can easily predict, observe and explain wave concept, but find it tough for transversal wave concept and longitudinal wave concept; (4) POE is probably not suited for some subjects or topics that require high thinking level. Predict stage should go well when students are learning common knowledge, but might not be the case with rare cases. Observe stage should go well with sensible knowledge, but might not suit abstract knowledge. Explain should go well if students have least required communication ability, else it might cause misunderstanding instead. To put it short, POE also has limitation but can be solved by modifying the stages in POE by adding, removing or replacing one or some stages in POE to suit the subjects/topics. In its implementation, the teacher might want to consider what concept to be taught with POE strategy. 


\section{ACKNOWLEDGMENT}

Many supports have been received by the researcher so that this could have been conducted. Through this study, the researcher would like to give acknowledgment to the school that had allowed for the research to take place. Secondly, for those who had given supports to help provide information, guidance and so on by the judges, lecturers, university staffs, and many others that are not mentioned.

\section{REFERENCES}

Anderson, L. W., Krathwohl, D. R., Airasian, P. W., Cruikshank, K. A. Mayer, R. E., Pintrich, P. R., ... \& Wittrock, M. C. (2001). A Taxonomy For Learning, Teaching, and Assessing: A Revision Of Bloom's Taxonomy of Educational Objectives, Abridged Edition. White Plains, NY: Longman.

Cholisoh, L., S. Fatimah, \& F. Yuniasih. (2015). Critical Thinking Skills in Integrated Science Learning Viewed from Learning Motivation. Jurnal Pendidikan Fisika Indonesia, 11(2), 134-141.

Clark, Donald. (2015, January 12). Bloom's Taxonomy of Learning Domains: The Cognitive Domain. Retrieved on November 9, 2016, from http://www.nwlink.com/ donclark/hrd/bloom.html

Fraenkel, J. R., Wallen, N. E., \& Hyun, H. H. (2011). How to Design and Evaluate Research in Education. New York: Mc. Graw Hill

Hake, R.R. (1999). Analyzing Change/Gain Scores. Dept. of Physics, Indiana University 24245 Hatteras Street, Woodland Hills, CA, 91367 USA.

Hamalik, O. 2009. Psikologi Belajar dan Mengajar (6 $6^{\text {th }}$ edition). Bandung: PT Grasindo.

Hilario, J.S. (2015). The Use of Predict-Observe-Explain-Explore (POEE) as a New Teaching Strategy in General ChemistryLaboratory. International Journal of Education and Research, 2(3), 38-39.

Indonesian Ministry of Education and Culture. (2015). Republic of Indonesia Government Regulation No. 19 Year 2005 About National Standard of Education. Jakarta: Kemendikbud.

Johnson, E. B. (2010). Menjadikan Kegiatan Belajar-Mengajar Mengasyikkan dan Bermakna (Indonesian Translation from the original Contextual Teaching \& Learning: What It Is and Why It's Hero To Stay). Bandung: Penerbit Kaifa.
Kala, N., Yaman, F. \& Ayas, A. (2012). The Effectiveness of PredictObserve-Explain Technique in Probing Students' Understanding about Acid-Base Chemistry: A Case for The Concepts of $\mathrm{pH}$, $\mathrm{pOH}$, And Strength. International Journal of Science and Mathematics Education, 11(1), 570-571.

Kibirige, I., Osodo, J. \& Tlala, K.M. (2014). The Effect of PredictObserve-Explain Strategy on Learners' Misconceptions about Dissolved Salts. Mediterranean Journal of Social Sciences, 5(4), 301-304.

Nana, Sajidan, Akhyar, M., \& Rochsantiningsih, D. (2014). The Development Of Predict, Observe, Explain, Elaborate, Write, And Evaluate (POE2WE) Learning Model In Physics Learning At Senior Secondary School. Journal of Education and Practice, 5(19), 5758

Paul, R.W., \& Elder, L. (2009). The Miniature Guide to Critical Thinking Concepts \& Tools (6th Edition). CA: The Foundation for Critical Thinking.

Pratama (2012) Hubungan antara Kecenderungan Berpikir Kritis Dengan Indeks Prestasi Kumulatif (IPK) Mahasiswa Prodi Dokter FK UNDIP. Report of research. Universitas Diponegoro, Semarang.

Slavin (1997). Educational Psychology Theory and Practice, Fifth Edition. Boston: Allin and Bacon.

Ulfah, Q.N., Asim \& Parno (2014). Penerapan Model Pembelajaran Poe (Predict-Observe-Explain) Untuk Meningkatkan Kemampuan Berpikir Kritis dan Motivasi Belajar Siswa Kelas X-Mia 4 Sma N 6 Malang dalam Materi Fisika Kalor. Universitas Negeri Malang, Malang.

Wardani, T. B., \& Winarno, N. (2017). Using Inquiry-based Laboratory Activities in Lights and Optics Topic to Improve Students' Understanding About Nature of Science (NOS). Journal of Science Learning, 1(1), 28-35.

Wardatun, H., Dwiastuti, S. \& Karyanto, Puguh (2015). The Influence of Predict Observe Explain Write Towards of Critical Thinking Skills and in X Degree SMA N 2 Sukoharjo in academic year on 2012/2013. Universitas Sebelas Maret, Surakarta.

White, R., \& Gunstone, R. (2014). Prediction-Observation-Explanation. Probing Understanding, 4. Routledge, 2014.

Wijaya, C. (2007). Pendidikan Re-medial Sarana Pengembangan Mutu Sumber Daya Manusia. Bandung: Remaja Rosdakarya.

Zulaeha, I.W., Darmadi \& K. Werdhiana (2014). Pengaruh Model Pembelajaran Predict, Observe And Explain terhadap Keterampilan Proses Sains Siswa Kelas X Sma Negeri 1 Balaesang. Universitas Tadulako, Palu. 